\title{
Effects of low dose intravenous sodium nitrite on arterial oxygenation and hemodynamics in experimental acute respiratory distress syndrome (ARDS)
}

\author{
S Kronfeldt ${ }^{\text {* }}$, P Lother ${ }^{1}$, RCE Francis ${ }^{1}$, T Busch $^{2}$, W Boemke ${ }^{1}$, PA Pickerodt ${ }^{1}$, ER Swenson ${ }^{3,4}$ \\ From ESICM LIVES 2015 \\ Berlin, Germany. 3-7 October 2015
}

\section{Introduction}

Nitrite $\left(\mathrm{NO}_{2}{ }^{-}\right)$is an endogenous storage pool for nitric oxide (NO) [1]. We showed that sodium nitrite $\left(\mathrm{NaNO}_{2}\right)$ mitigates ventilator-induced lung injury via $\mathrm{NO}$ dependent mechanisms in rats [2].

\section{Objectives}

We hypothesized that low dose intravenous (i.v.) $\mathrm{NaNO}_{2}$ may improve arterial oxygenation and reduce mean pulmonary artery pressure (MPAP) and pulmonary vascular resistance (PVR) in ARDS in pigs.

\section{Methods}

ARDS was induced in 12 pigs by surfactant depletion due to saline lung lavages [3]. Two groups were investigated for $5 \mathrm{~h}$ : 1 . Controls $(\mathrm{n}=6)$ and $2 . \mathrm{NaNO}_{2}$ i.v. $(0.3 \mathrm{mg} / \mathrm{kg}$
BW bolus, followed by $0.1725 \mathrm{mg} / \mathrm{kg}$ BW continuously; $\mathrm{n}=6$ ). We measured mean arterial pressure (MAP), MPAP and cardiac output as well as exhaled NO (NOex), blood gases and Wet/Dry-Ratios of lung tissue.

\section{Results}

At baseline the arterial oxygen tension $\left(\mathrm{P}_{\mathrm{a}} \mathrm{O}_{2}\right)$ was $539 \pm$ $50 \mathrm{mmHg}$ and $508 \pm 35 \mathrm{mmHg}$ in Controls and $\mathrm{NaNO}_{2}$ i.v. respectively (fraction of inspired oxygen $=1.0$ ). $\mathrm{P}_{\mathrm{a}} \mathrm{O}_{2}$ decreased to $67 \pm 17 \mathrm{mmHg}$ (Controls) and $57 \pm 13$ $\mathrm{mmHg}\left(\mathrm{NaNO}_{2}\right.$ i.v. $)$ after ARDS induction. During the protocol, $\mathrm{P}_{\mathrm{a}} \mathrm{O}_{2}$ increased to $120 \pm 73 \mathrm{mmHg}$ (Controls) and $103 \pm 82 \mathrm{mmHg}\left(\mathrm{NaNO}_{2}\right.$ i.v.). NOex was unchanged in both groups. Lung Wet/Dry-Ratios were $8.1 \pm 0.8$ (Controls) and $8.9 \pm 0.7\left(\mathrm{NaNO}_{2}\right.$ i.v.). For hemodynamic values see Table 1 (all values: mean $\pm \mathrm{SD}$ ).

Table 1

\begin{tabular}{ccccccc}
\hline Groups & TP & MPAP $(\mathbf{m m H g})$ & PVR $\left(\mathbf{d y n} \boldsymbol{s}^{*} \mathbf{c m}-\mathbf{5}\right)$ & MAP $(\mathbf{m m H g})$ & SVR (dyn*s*cm-5) & CO (L/min) \\
\hline Controls & T0 & $14 \pm 3$ & $205 \pm 107$ & $92 \pm 6$ & $2157 \pm 520$ & $3.5 \pm 0.9$ \\
\hline & T1 & $33 \pm 6$ & $360 \pm 97$ & $74 \pm 13$ & $966 \pm 212$ & $6.2 \pm 0.7$ \\
\hline T2 & $27 \pm 5$ & $243 \pm 78$ & $67 \pm 10$ & $798 \pm 196$ & $6.6 \pm 0.9$ \\
\hline \hline NaNO2 i.v. low dose & T0 & $15 \pm 1$ & $185 \pm 26$ & $90 \pm 13$ & $1967 \pm 417$ & $3.7 \pm 0.4$ \\
\hline & T1 & $34 \pm 3$ & $429 \pm 78$ & $72 \pm 10$ & $1092 \pm 293$ & $5.1 \pm 0.5$ \\
\hline
\end{tabular}

Mean pulmonary artery pressure (MPAP), pulmonary vascular resistance (PVR), mean arterial pressure (MAP), systemic vascular resistance (SVR), cardiac output (CO) in control animals (Controls; $\mathrm{n}=6$ ) and in animals treated with low dose intravenous sodium nitrite ( $\mathrm{NaNO2}$ i.v.; $\mathrm{n}=6$ ); Time point of measurement (TP): Baseline (T0); ARDS baseline (T1); End of experiment (T2); All values: mean \pm SD

'Charité - Universitätsmedizin Berlin, Department of Anesthesiology and Intensive Care Medicine, Campus Charité Mitte and Campus VirchowKlinikum, Berlin, Germany 


\section{Conclusions}

Lung lavage induced severe ARDS with increased MPAP and PVR in both groups. I.v. application of low dose $\mathrm{NaNO}_{2}$ did not reduce lung edema formation and did not improve arterial oxygenation or pulmonary hemodynamics in this model of severe ARDS in pigs.

\section{Grant Acknowledgment}

This study was supported by the Deutsche Forschungsgemeinschaft (PI795/2-1).

\section{Authors' details}

'Charité - Universitätsmedizin Berlin, Department of Anesthesiology and Intensive Care Medicine, Campus Charité Mitte and Campus VirchowKlinikum, Berlin, Germany. ${ }^{2}$ Universität Leipzig, Department of Anesthesiology and Intensive Care Medicine, Leipzig, Germany. ${ }^{3}$ University of Washington, Department of Pulmonary and Critical Care Medicine, Seattle, WA, USA.

${ }^{4}$ Veterans Affairs Puget Sound Health Care System, Seattle, WA, USA.

Published: 1 October 2015

\section{References}

1. Lundberg JO, Weitzberg E, Gladwin MT: The nitrate-nitrite-nitric oxide pathway in physiology and therapeutics. NatRev Drug Discov 2008, 7(2):156-167.

2. Pickerodt PA, Emery MJ, Zarndt R, Martin W, Francis RC, Boemke W, Swenson ER: Sodium nitrite mitigates ventilator-induced lung injury in rats. Anesthesiology 2012, 117(3):592-601.

3. Lachmann B, Robertson B, Vogel J: In vivo lung lavage as an experimental model of the respiratory distress syndrome. Acta Anaesthesiol Scand 1980, 24(3):231-236.

doi:10.1186/2197-425X-3-S1-A574

Cite this article as: Kronfeldt et al:: Effects of low dose intravenous sodium nitrite on arterial oxygenation and hemodynamics in experimental acute respiratory distress syndrome (ARDS). Intensive Care Medicine Experimental 2015 3(Suppl 1):A574.

\section{Submit your manuscript to a SpringerOpen ${ }^{\circ}$ journal and benefit from:}

- Convenient online submission

- Rigorous peer review

- Immediate publication on acceptance

- Open access: articles freely available online

- High visibility within the field

- Retaining the copyright to your article 